\title{
Determination of new hematologic reference intervals for sows with optimal reproductive performance, according to reproductive stage, parity and body condition: A cohort study
}

\section{Carolina Baeza ( $\nabla$ carolbaeza@udec.cl)}

Universidad de Concepción - Campus Chillán: Universidad de Concepcion - Campus Chillan https://orcid.org/0000-0002-7774-9509

\section{Paula Gädicke}

Universidad de Concepción - Campus Chillán: Universidad de Concepcion - Campus Chillan Álvaro Ruiz

Universidad de Concepción - Campus Chillán: Universidad de Concepcion - Campus Chillan

\section{Research}

Keywords: swine, reference intervals, hematology, sow, reproduction

Posted Date: March 31st, 2021

DOl: https://doi.org/10.21203/rs.3.rs-317100/v1

License: (c) (1) This work is licensed under a Creative Commons Attribution 4.0 International License.

Read Full License 


\section{Abstract}

Background. Inappropriate feeding and reproductive management according to strategies in sow's reproductive efficiency produce important consequences on sow metabolism. The metabolic alterations can increase mortality and reduce fertility, productivity and lifespan of sows within a farm, decreasing herd output. In according to that, this research aimed to determine the effect of reproductive stage, parity and body condition on hematological parameters of intensive-production sows and also to establish new and representative hematological Reference Intervals for each stage of the reproductive cycle in Chilean sows of optimal reproductive performance. In order to that, a cohort study in 307 healthy sows from two farms was performed. Serial hemograms were obtained and sows were monitored at weaning, prior to artificial insemination, at 35, 60 and 90 days of gestation, and subsequent weaning. Results were analyzed by Repeated-Measures of Anova and Tukey Test to establish differences between times and by the Kruskall-Wallis Test, or Simple Anova Test, to determine differences within times caused by the body condition (BC) or sow age.

Results: Significant differences were found in most factors during gestation $(P=0,00)$. At each time frame considered, there was an effect of parity. The sowsparityhis $\rightarrow r y$, their $B C$ and thefarms infrastructure and environment were all relevant factors in each hematological parameter. Additionally, statistically significant differences in almost all the evaluated indicators were contrasted with reference IRs $(P=0,00)$. Hematological indicators supported the interaction between $B C$ and parity in some sows.

\section{Conclusions}

This study showed the need of not only specific reference intervals for high-production sows, but also highlights the relevance of considering the different stages of sows's reproductive cycle. Consideration of sow's physiological stage and parity, along with body condition appear to be highly relevant to get appropriate hematologic reference intervals.

\section{Background}

Inappropriate feeding and reproductive management in sow husbandry can cause metabolic disturbances. Besides, the industrial advancements strategies in sow's reproductive efficiency has produced important consequences on sow metabolism due to high productive requirements resulting in alterations which are sometimes difficult to diagnose [1]. These alterations can increase mortality and reduce fertility, productivity and lifespan of sows within a farm, decreasing herd output. Hematological results, as one of the most useful tests in clinical practice in the assessment of health and early detection of diseases [2]. However, low individual animal intrinsic value, sample collection difficulty and different husbandry techniques make this tool a rarely-used resource in swine [2].

The reference intervals (RIs) for hematological results, describe the dispersion of variables in healthy specimens and are based on $95 \%$ of the healthy population [3]. However, as in majority of mammal, 
different stages of development. Thus, good and adapted Rls are indispensable for proper interpretation of blood tests [4]. In this sense, the difficulties for determining hematological Rls in pigs are based on the pronounced fluctuation of these hematological values, depending on age, time of year, farm, nutrition, handling, genetic factors, gestation and lactation period [3,5]. Previous hematological studies proposed erratic reference values, have used small sample sizes, uncommon breeds, among other factors.

Therefore, they are no longer representative of present-day sow production in Chile $[1,4,6,7,8]$. Moreover, to our knowledge, there are no current studies considering the sow's whole reproductive cycle. Therefore, this research aimed to determine the effect of age (parity), body condition (BC), farm settings and physiological status on hematological parameters of intensive-production sows and also to establish new and representative hematological Rls for each stage of the reproductive cycle in Chilean sows of optimal reproductive performance. This will help to establish differences with information reported in the literature, following the guidelines published by the American Society of Veterinary Clinical Pathology (ASVCP) [2].

\section{Results}

\section{Effect of the reproductive cycle on hematological values}

Figure 1 shows hematological values for sows at the stages of the productive cycle. We compared the IR calculated with available literature $[7,4,5]$ by means of t test, statistical differences were determined in Hct $(P=0.000), \mathrm{Hb}(P=0.000), \mathrm{PP}(P=0.000)$, WBC $(P=0.000)$, Eos $(P=0.000)$, Lymph $(P=0.000)$, Seg $(P=$ 0.000). In the case of PLT, no difference was detected with the IR published by Loynachan 2012 [5] and the IR of early gestation (T3) $(P=0.083)$ and subsequent weaning $(T 6)(P=0.7392)$. When comparing monocytes IR, they did not present a difference only at weaning $(\mathrm{T} 1)(P=0.491)$ and in the middle of gestation (T4) $(P=0.09)$ and the IR presented by Bhattarai, 2019 [4], the IR of the Early gestation (T3) did not show a difference with the RI of Loynachan 2012 [5].

When comparing IRs throughout the production cycle we can observe statistically significant differences the following hematological parameters: $\mathrm{Rl}$ : $\mathrm{Hb}(P=0,00)$, WBC $(P=0,00)$, Lymph $(P=0,00)$, Seg $(P$ $=0,00)$, and Eos $(P=0,00)$; Conversely, there was no effect on the Mon $(P=0.52)$ and $\mathrm{PP}(P=0.11)$. Hct, PLT was not significantly different to Rls even though a trend is observed $(P=0,06)$. Hct and $\mathrm{Hb}$ values increased steadily until day 35 of gestation (T3) and Lymph values showed a constant decrease until the weaning stage (T6) (Figure 1). Seg values increased during the weaning process and the lowest values were found during gestation ( $P=0.00)$; The Eos values $(P=0.00)$ fluctuated, but increased before insemination (T2) and at day 60 of gestation.

\section{Effect of parity and body conditions at different productive stages}

Body condition 3 (BC3) was not included in the analyses because the number of sows were small (9), none of them in parity 1 . Therefore, only BC1 (thin) and BC 2 (normal) were included. 
Table 1 shows variation of the hematological values according to parity and body condition before pregnancy. For weaning stage sow parity generated an effect on $\operatorname{Hct}(P=0.00)$; PP and WBC $(P=0.01)$; and Lymph $(P=0.00)$. The levels of Hct, WBC and Seg decreased as the sow age increased $(P=0.00)$, and Lymph and Eos values reached the highest levels in older sows (parity 3). At Pre insemination BC only had an effect on $\mathrm{Hb}(P=0.01)$, and $\mathrm{PP}(P=0.02)$ in first-parity sows, which had the thinnest sows in comparison to the optimal $\mathrm{BC}$ sows. Previous to insemination, PP showed an increasing trend regarding sow age $(P=0.02)$, besides, WBC values decreased after the third parity $(P=0.01)$. First-parity thin sows presented lower $\mathrm{Hct}, \mathrm{Hb}(P=0.02), \mathrm{PLT}(P=0.03)$, and WBC $(P=0.02)$ than sows in optimal BC.

Table 2 shows variation of the hematological values according to parity and body condition during pregnancy. At 35 days of pregnancy, Hct $(P=0.04)$ and WBC $(P=0.027)$ levels decreased with age. In the case of first-parity sows, there were differences in the $\operatorname{Hct}(P=0.03)$ and $\mathrm{Hb}(P=0.01)$ values, and optimal condition sows had higher levels of $\operatorname{Hct}(P=0.04)$ and $\mathrm{Hb}(P=0,00)$. The effect of parity was significant at 60 days of pregnancy in PP and WBC $(P=0.00)$ values, showing increasing and decreasing levels, respectively, as age increased. BC had an effect on $\operatorname{Hct}(P=0.04)$ and $\operatorname{PP}(P=0.00)$ levels, but only for first-parity sows. At day 90 of pregnancy, $\mathrm{Hct}, \mathrm{Hb}$ and WBC $(P=0.00)$ had higher values in younger sows, which decreased progressively.

Finally, Table 4 shows variation of the hematological values according to parity and body condition after pregnancy. Parity generated differences at subsequent weaning in PP $(P=0.020)$ and $\operatorname{Lymph}(P=0.01)$, which trended to increase with sow age. Sow BC generated a difference only for first-parity specimens in WBC $(P=0.01)$ and Seg $(P=0.00)$, proving the trend for thinner first-parity sows as the lowest-level indicators. The Rls were established in each of the parities according to the interaction that was detected between age and gestation period in: $\operatorname{Hct}(\mathrm{P}=0.04), \mathrm{PP}(P=0.02)$ and $\mathrm{PLT}(P=0.03)$.

\section{Discussion}

The hematologic Rls obtained in this study are different from those previously reported in the literature, probably because those studies were developed in different experimental models of pigs and did not differentiate results according to the productive stage, $B C$ or age $[1,4,6,7,8,18]$. Due to the evidence existence of factors like physiological state, weight can vary hematological values, we now propose new hematological RIs for sows, based on productive stage. These factors should be considered for porcine hematology data interpretation and could prevent incorrect clinical diagnoses for blood count test.

The changes in hematological parameters from day 35 of pregnancy showed a considerable decrease of blood cells and an increase in plasma proteins throughout sow gestation which were probably due to physiological pregnancy hemodilution occurrences, which has been previously reported in other species $[1,15,16,17,18]$. This hemodilution can produce a plasma volume increase of $30-50 \%$ during pregnancy, generating a constant decline of Hct and cell count, as pregnancy progresses [15]. The expansion in plasma volume depends on a physiological condition of pregnancy corresponding to increased activity of tho ronin-annintoncin-aldnctornno cyctom and incroacod water retention due to sodium ( $\mathrm{Na}+)$ Loading [MathJax]/jax/output/CommonHTML/fonts/TeX/fontdata.js 
reabsorption from the kidneys [15]. The hemodilution in late pregnancy observed in domestic animals may have a physiological importance as it reduces blood viscosity and thereby, greatly increases blood flow in the small blood vessels, and facilitates the increase in blood flow to vital organs, such as the kidneys and uterus $[15,19]$.

The effect of parity on blood cells might be due to the direct relationship with the amount hematopoietic cells. Several reports have indicated a physiological reduction in the production of erythrocytes and white blood cell count by lesser quantities of bone marrow cells, according to age of pigs [20]. Young sows, during the first gestations, are still in the growth and development processes and therefore, consumption of proteins is destined both to the fetuses and sow growth. Of note, the plasma protein concentration could be more sensitive to the amount of ingested protein [21]. The increase in plasma proteins is in agreement with other studies that associate the increase of age during the adult stage to a halt of the development process and growth [4]. In this study, it was essential to us to inform the RIs for each of the parities $(1,2,3)$ and body condition (thin, optimal) at the different times evaluated, because interactions indicate the need to analyze hematological values together for each level, and it was also the main goal of these research.

The body condition generated an evident effect on first-parity sows. This could be due to the increase of protein demand during the sow's growth stage, which has been informed to be notorious during gestation [21].

Among the hematological changes during the sow productive cycle, hypervolemia during pregnancy is also crucial to protect the mother and the fetus from the adverse effects of blood loss during delivery $[15,17]$. A reduction of the hematocrit value will result in false anemia during pregnancy [18]. Moreover, this hemodilution could explain the constant decrease of platelets throughout the gestation period and the lowest concentration of blood cells during the 90 days of gestation [22]. Besides, total white blood cell count decreases during gestation, and anemia during pregnancy has been documented in sows $[4,18]$. This could be explained due to the effect of hemodilution during pregnancy because there is a documented reduction of all the figurative elements [19]. Therefore, this physiological anemia could explain the gradual increase of plasma proteins during pregnancy mainly because secretion of albumin is stimulated by a decrease of osmotic pressure in plasma [23]. Moreover, some hormones, such as testosterone, estrogens, and growth hormone, promote an increase in plasma proteins because of their anabolic effects, to avoid edema, ascites and hydrothorax as a physiological response20. In our study, monocytes showed similar behavior to total white blood cell count and hematocrit, which could coincide with the dilution effect due to plasma increase.

Interestingly, we detected an inverse relationship between hematocrit and parity. The youngest sows (parities one and two) presented higher hematocrit percentages than sows of higher parities. This effect could be due to two factors. Firstly, hematocrit values tend to be higher in younger animals because the bone marrow is expanding, which contributes to hematopoiesis [18]. However, the demand for enuthronvites at maturity limits thic funntion to Inna hones; thus, hematopoiesis decreases and red marrow Loading [MathJax]/jax/output/CommonHTML/fonts/TeX/fontdata.js 
is replaced by fatty tissue [18]. Secondly, young animals tend to be more susceptible to stress, which generates splenic contraction, producing a relative polycythemia by stimulation of the sampling process [22]. This hypothesis is reinforced by analyzing the white blood cell count, which is higher in younger animals and could be indicative of leukogram due to stress $[4,18]$.

The interactions of hematocrit, plasma proteins, platelets and parity of sows during the time of the study are important and therefore, we believe it becomes necessary to inform the IR for each of the parities.

In this study, segmented neutrophils were highest at weaning and subsequent weaning and increased white blood cell count during these periods but decreased the Lymph count. In this respect, neutrophilia and lymphopenia frequently occur at parturition in sows, an effect that could be generated by the rise of cortisol associated to the accouchement [4]. Cortisol has a considerable impact on blood cells, including a reduction of lymph, a rise in the number of segmented neutrophils and total white blood cell count [23]. In this sense, it is well-known that leukogram stress is more neutrophilic than lymphophilic and is associated with a transient increase of hematocrit [4]. However, we must consider that sampling stress is the largest source of hematologic variation in swine and develops within two minutes, rapidly affecting the leukogram $[4,24]$. Another possible cause of increase is that segmented neutrophils play an important role in eliminating udder pathogens by phagocytosis and subsequently, killing bacteria, an important function during lactation [16].

Lymphocytes and segmented neutrophil counts increased more during early pregnancy (T3) than in the non-pregnant stages, as has been reported in mares, monkeys and women $[15,17,25]$. This is due to an increased inflammatory response during normal pregnancy, which can be a consequence of selective immune tolerance, immunosuppression and immunomodulation of the fetus [26]. All these factors may be related to the decreased immune function of maternal cells, the suppression of specific immune functions and a compensatory increase in non-specific immunity [19]. The different interaction level of eosinophils with farm origin could be due to the ventilation conditions of the farm, since the amount of ammonia perceptible at the time of sampling causes irritation of the respiratory system [22].

Regarding reference intervals, we can highlight that this study complies with all the recommendations of the ASVCP, in addition to the individual monitoring of sows during their reproductive cycle. Establishing reference intervals is essential to determine normality or alterations of some of the hemogram parameters, which provide fundamental information for the interpretation of exams [2]. Other reference intervals reported in the literature are broad and probably not representative because they did not consider the different stages of sow physiological state. Furthermore, these previous studies were established from smaller size samples or specific moments of the reproductive cycle $[4,6,20,22]$. Therefore, we strongly believe that the proposed RIs in our study are more precise, because we have included main of the factors that generated effects and interactions for variation of the reference intervals.

Despite our analysis, our study has some shortcomings, a) although we had a relatively appropriate Loading [MathJax]/jax/output/CommonHTML/fonts/TeX/fontdata.js examined group could affect the statistical 
power, b) even though the two farms used to collect sows were similar in production and management terms, some differences in, for example, vaccination plans or microclimate, could affect homogeneity of the sample, c) some other potentially candidate factors were not evaluated in this study and other biochemical parameters (e.g. creatine kinase, aminotransferase activities, albumin, bilirubin, urea concentrations, among others) might be also important.

In conclusion, the present proposed reference intervals could constitute a sensitive tool to determine some hematological alterations in industrial production sows, particularly in highly industrialized swine production in Chile and other countries with similar productive management.

\section{Materials And Methods}

\section{Study Design and Ethics}

This research is a prospective cohort study in sows, carried in Central Chile, which included a highperforming Chilean farrow-to-finish sow herd of 307 specimens from two commercial farms whose housing was adequate and allowed human treatment of the animals.

The samples were taken from September 2017 to May 2018 from two similar farms; the first one was located in the Maule Region and the second one was located in the Nuble Region. The herds were selected according to convenience of locations and farm operation volume. We chose 2,500 sows from Maule region with 48 farrowing per week, and 3,750 sows from Ñuble región with 72 farrowing per week.

\section{Sows selection and managements}

To estimate the $95 \%$ of specimens with optimal reproductive performance, a $3 \%$ margin of error provided 97.5\% confidence, from a total of 266 sows to be tested to generate valid RIs (WinEpi: Working in Epidemiology) [10]. However, convenience sampling was performed, taking the total sows weaned at 5 productive weeks ( $n=452$ sows), discarding those that: were sampled less than 4 times, showed reproductive performance flaws and a sow that died during gestation. 307 sows remained after discarding the sows with reproductive failure: those showing oestrus repetition, parturition of 10 or less live piglets or abortion. Sows of PIC genetic lines 1020 and 1050 were individually monitored during a whole reproductive cycle (184 specimens from Farm A with and 123 from Farm B). These sows must have had between 1 to 8 parities, and optimal reproduction performance (none of the mentioned flaws). All sows evaluated in this study were inspected and considered clinically healthy by veterinarians at the time of blood sampling. None of the sows selected for sampling had any skin lesions, nor did they suffer from diarrhea, coughing or lameness [11]. The 307 sows were classified according to two parameters: i) BC, using a simplified scale of 3 degrees: 1 : thin; 2 : optimal; and 3 : fat, according to the Charalette scale12; and ii) parity: first (parity 1), second (parity 2), third or more (parity 3 ). The average live weight of the sows fluctuated between 180 and $240 \mathrm{~kg}$. In each sampling, the BC of the sow was recorded. 
Chilean swine production is free of foot-and-mouth disease, Brucella suis, Porcine epidemic diarrhea, Pseudorabies, Classical and African Swine Fever and Porcine Reproductive and Respiratory Syndrome (PRRS) [13]. Thus, all sows were vaccinated against Porcine Parvovirus (PPV), Leptospira spp., Erysipelothrix rhusiopathiae, Swine Influenza Virus (SIV) and Escherichia coli during the gestational period. Additionally, in Farm A sows were vaccinated against Clostridium perfringens beta toxoid, and Farm B sows, against Actinobacillus pleuropneumoniae.

Both farm owners provided information about feeding regimes, including feeding intervals, categorydependent diets, and feed consumption. Sows were fed one portion per 24-hour period, between 7 and 8 AM. The sow's general diet consisted of corn and soybeans, supplemented with a complementary feed consisting of mineral and vitamin mixtures, according to the National Research Council (NRC)category recommendations [14].

Pregnant sows were on a restricted feeding regime depending on their $\mathrm{BC}$, while the lactating sows were fed ad libitum. All sows had free access to water from nipple drinkers, lived under the same conditions and were individually contained.

\section{Blood sample collection and hematological analysis}

The individual blood sample collections were carried out between September 2017 and May 2018. Each sow was sampled a total of six times: during the time of weaning (T1), pre-artificial insemination (T2), day 35 of pregnancy (T3), day 60 of pregnancy (T4), day 90 of pregnancy (T5) and at the time of subsequent weaning (T6). The blood samples were collected from the jugular external vein for hematological analysis in $4 \mathrm{~mL}$ tubes containing ethylene diamine tetra-acetic acid (EDTA) (Vacuette, Greiner Bio-One $\mathrm{GmbH}$, Kremsmünster, Austria). Tubes were gently mixed by hand for 30 seconds to assure proper mixture between the blood and the anticoagulant. All blood samples were collected between 9 and 11 AM in both farms, approximately 2-3 hours after sow feeding. Animals were restrained using wire-noose snares and blood sampling was carried out by a skilled person with sow welfare consideration.

Blood samples were maintained in a cooler and then transported to the Pathology Clinic Laboratory at Universidad de Concepción for analysis with the Human Count 30 machine (Wiesbaden, Germany). The following hematological variables were measured: plasma proteins (PP), platelet count (PLT), white blood cell count (WBC) and differential WBC, according to standard procedures. Smears stained with Hemacolor (Merck, Darmstadt, Germany) and manually counted via microscopic examination differentiated: eosinofils (Eos), lymphocytes (Lymph), monocytes (Mono) and segmented neutrophils (Seg). Hematocrits (Hct) were evaluated through precipitation of red blood cells and hemoglobin $(\mathrm{Hb})$ was quantified by the Drabkin method.

\section{Statistical analysis}


For hematologic variables, descriptive statistics were calculated to assess physiological status in different productive stages, parity and BC (thin, optimal and fat).

Normality-condition data was evaluated with the Shapiro-Wilk's test and a significance level of $5 \%$. When the distribution was not Gaussian, data were transformed using log or Box-Cox transformation. Potential differences associated with farm, parity or BC were assessed using the repeated-measures ANOVA test, followed by a posterior Tuckey's test, when the value of the factor in the ANOVA test was $P<0.05$. A Kruskall-Wallis test, as well as pair testing were used for the analysis of variables that did not meet the normality-condition criteria. Statistical analysis of hematological data was performed using the Stata Software Package (Stata 13.0 for Mac, Texas, USA). To determine the difference between the new RIs calculated and RIs on the literature was performed t-test. Atypical values were evaluated with the Dixon test, considering $P$ values $<0.05$

The RIs were generated from samples of clinically-healthy and optimal reproductive performance sows, stratifying them for statistically significant variables using the same pre-analytical and analytical procedures. As a reference, we used the "Reference Value Advisor v2.1" approaches, as recommended by the ASVCP guidelines [2].

\section{Declarations}

\section{Ethics approval and consent to participate}

All procedures complied with the Chilean legislation through the Animal Protection Law 203809 and were approved by the Ethics Committee for Animal Studies of Universidad de Concepcion (approval number: 02-18, 04-2018).

\section{Consent for publication}

Not applicable.

\section{Availability of data and materials}

The datasets used and/or analysed during the current study are available from the corresponding author on reasonable request.

\section{Competing interests}

The authors declare that they have no competing interests.

\section{Funding}

The research was funded by the Porcino Diagnostic Laboratory at the college of Veterinary Medicine, Universidad de Concepción, Campus Chillan, Chile, and Fellowship CONICYT PFCHA/Doctorado 


\section{Authors' contributions}

PCG, CAB conceived of the presented idea. ARR PCG and CAB planned the study and conceived the review design of investigation. $C A B$ and was a major contributor in the writing of the manuscript. Statistical analyses were performed by CAB and PCG with contribution from ARR provided technical and scientific support on the analysis. ARR supervised the project.

The authors read and approved the final manuscript.

\section{Acknowledgements}

The authors acknowledge the two herd owners and staff for their cooperation and assistance with the study, and we acknowledge the excellent technical assistance provided by Stephanie Andrade and Karen Fernandez

\section{References}

1. Žvorc Z, Mrljak V, Sušić V, Pompe Gotal J. Haematological and biochemical parameters during pregnancy and lactation in sows. Vet Arh. 2006; 76:245-53.

2. Perri AM, O'Sullivan TL, Harding JCS, Wood RD, Friendship RM. Hematology and biochemistry reference intervals for Ontario commercial nursing pigs close to the time of weaning. Can $J$ Vet Res. 2017; 58:371-6.

3. Friedrichs KR, Harr KE, Freeman KP, et al. ASVCP reference interval guidelines: determination of de novo reference intervals in veterinary species and other related topics. Vet Clin Pathol. 2012; 41:44153.

4. Thorn CE. Hematology of the Pig. In: Weiss DJ, Wardrop KJ, editors. Schalm's Veterinary Hematology. $6^{\text {th }}$ ed: Wiley Blackwell; 2010. p. 843-51.

5. Loynachan AT. Cardiovascular and Hematopoietic Systems. In: Zimmerman JJ, Karriker LA, Ramirez A, Schwartz KJ, Stevenson GW, editors. Disease of Swine. $10^{\text {th }}$ ed: Wiley-Blackwell; lowa 2012. p. 189-98.

6. Ježek J, Starič J, Nemec M, Plut J, Golinar I, Klinkon, Štukelj M. The influence of age, farm, and physiological status on pig hematological profiles. J Swine Health Prod. 2018; 26: 72-8.

7. Bhattarai S, Framstad T, Nielsen JP. Hematologic reference intervals of Danish sows at midgestation. Acta Vet Scand. 2019; 61(1).

8. Mersmann HJ, Pond WG. Hematology and blood serum constituents. In: Pond WG, Mersmann HJ, editors. Biology of the domestic pig. New York: Cornell University; 2001. p. 560-84.

9. Subsecretaría de Salud Pública. Ley Sobre Protección de Animales (Animal Protection Law). http://www.leychile.cl/Navegar/?idNorma=1006858\&idVersion=20 09-10-03\&idParte. Ley 20380. Published October 2009. Accessed September 10, 2020. 
10. Ortega C, de Blas I, Simón M, Gironés O, García J, Alonso JL, Muzquiz JL, Ruiz I. Programa informático aplicado al estudio temporal de procesos patológicos en poblaciones animales (Computer program applied to the temporary study of pathological processes in animal populations). Rev Sci Tech. 2000; 19:735-43.

11. Daza A. [Optimización de la productividad numérica en las repoductoras; perspectivas] Optimization of numerical productivity in breeders; prospects. In: Carbó CB, editors. Producción porcina: aspectos claves (Swine production: key aspects). $2^{\text {nd }}$ ed: Mundo Prensa; 1999. p. 151-74.

12. Charette R, Bigras-Poulin M, Martineau G-P. Body condition evaluation in sows. Livest Prod Sci. 1996; 46:107-15.

13. Servicio Agrícola y Ganadero. Notificación de ausencia/presencia de enfermedades de la lista OIE II semestre 2018 (Notification of absence / presence of diseases of the OIE list - II semester 2018). https://www.sag.gob.cl/sites/default/files/informe_oie_ii-semestre_2018.pdf. Published 2018. Accessed September 30, 2020.

14. National Research Council. Nutrient Requirements of Swine. $11^{\text {th }}$ rev ed: Washington DC; 2012.

15. Bazzano M, Giannetto C, Fazio F, Rizzo M, Giudice E, Piccione G. Physiological adjustments of haematological profile during the last trimester of pregnancy and the early post partum period in mares. Anim Reprod Sci. 2014; 149:199-203.

16. Czech A, Grela ER. Biochemical and haematological blood parameters of sows during pregnancy and lactation fed the diet with different source and activity of phytase. Anim Feed Sci Technol. 2004; 116:211-23.

17. Bakrim S, Motiaa Y, Ouarour A, Masrar A. Hematological parameters of the blood count in a healthy population of pregnant women in the Northwest of Morocco (Tetouan-M'diq-Fnideq provinces). Pan Afr Med J. 2018; 29:1-12.

18. Estienne M, Clark-Deener S, Williams K. Growth performance and hematology characteristics in pigs treated with iron at weaning as influenced by nursery diets supplemented with copper. J Swine Health Prod. 2020; 28(4):190-203.

19. Bhattarai S, Framstad T, Nielsen JP. Stillbirths in relation to sow hematological parameters at farrowing: A cohort study. J. Swine Health Prod. 2018; 26: 215-222.

20. Elbers ARW, Geudeke MJ, van Rossem H, Kroon MC, Counotte CHM. Haematology and biochemistry reference values for sows kept under modern management conditions. Vet Q. 1994; 16: 127-30.

21. Kraeling RR, Webel SK. Current strategies for reproductive management of gilts and sows in North America. J Anim Sci Biotechnol. 2015; 6:3.

22. Stockham, Steven L., and Michael A. Scott. Fundamentals of veterinary clinical pathology. John Wiley \& Sons, Ames lowa 2013.

23. Harvey JW, Pate MG, Kivipelto J, Asquith RL. Clinical biochemistry of pregnant and nursing mares. Vet Clin Pathol. 2005; 34:248-54. 
24. Casas-Díaz E, Closa-Sebastià F, Marco I, Lavín S, Bach-Raich E, Cuenca R. Hematologic and biochemical reference intervals for Wild Boar (Sus scrofa) captured by cage trap. Vet Clin Pathol. 2015; 44: 215-22.

25. Ming-Ling W, Li G, Can Q, Llang ZG, Wen Z. Characteristics of blood chemistry, hematology, and lymphocyte subsets in pregnant rhesus monkeys. Chin J Nat Med. 2015; 13: 409-14.

26. Kaur S, Khan S, Nigam A. Hematological profile and pregnancy: a review. Int J Adv Med. 2014; 1: 6870.

\section{Tables}

Table 1: Hematological values of sows with different parities ${ }^{1}$ and body condition before pregnancy, at weaning (T1) and pre-insemination (T2). 


\begin{tabular}{|c|c|c|c|c|c|c|c|c|c|}
\hline \multirow[b]{2}{*}{ Parameter } & \multirow[b]{2}{*}{ Unit } & \multicolumn{2}{|c|}{ Parity 1} & \multicolumn{2}{|c|}{ Parity 2} & \multicolumn{2}{|c|}{ Parity 3} & \multirow{2}{*}{\multicolumn{2}{|c|}{$\begin{array}{c}\text { Herd } \\
\text { average } \\
\text { (median) }\end{array}$}} \\
\hline & & $\begin{array}{c}\text { BC 1 } \\
\mathrm{n}=24\end{array}$ & $\begin{array}{c}\text { BC } 2 \\
\mathrm{n}=32\end{array}$ & $\begin{array}{c}\text { BC } 1 \\
\mathrm{n}=28\end{array}$ & $\begin{array}{c}\text { BC } 2 \\
\mathrm{n}=38\end{array}$ & $\begin{array}{c}\text { BC } 1 \\
\mathrm{n}=55\end{array}$ & $\begin{array}{c}\text { BC } 2 \\
\mathrm{n}=130\end{array}$ & & \\
\hline \multicolumn{10}{|l|}{ Weaning } \\
\hline Hct & $\%$ & $\begin{array}{l}23.2^{-} \\
39.9^{\mathrm{B}}\end{array}$ & $\begin{array}{l}28.4^{-} \\
46.1^{\mathrm{B}}\end{array}$ & $\begin{array}{c}26.5^{-} \\
40.5^{\mathrm{AB}}\end{array}$ & $\begin{array}{c}27.6- \\
43.1^{\mathrm{AB}}\end{array}$ & $\begin{array}{l}27.2^{-} \\
39.8^{\mathrm{A}}\end{array}$ & $\begin{array}{c}27.8- \\
41^{\mathrm{A}}\end{array}$ & 0,000 & $34.9(35)$ \\
\hline $\mathrm{Hb}$ & $\mathrm{g} / \mathrm{L}$ & $\begin{array}{l}70.4- \\
126.2\end{array}$ & $\begin{array}{l}80.9- \\
134.5\end{array}$ & $\begin{array}{l}84.2- \\
142.2\end{array}$ & $\begin{array}{l}88.1- \\
141.1\end{array}$ & $\begin{array}{l}82.3- \\
154.8\end{array}$ & $\begin{array}{l}77.3- \\
132.4\end{array}$ & 0,414 & $\begin{array}{l}108.5 \\
(108)\end{array}$ \\
\hline PP & $g / L$ & $\begin{array}{l}62.9^{-} \\
85.1^{\mathrm{A}}\end{array}$ & $\begin{array}{l}56.8- \\
88.9^{\mathrm{A}}\end{array}$ & $\begin{array}{l}65.5- \\
91.9^{\mathrm{A}}\end{array}$ & $67.9-92.6^{\mathrm{A}}$ & $\begin{array}{c}73.4- \\
99^{\mathrm{B}}\end{array}$ & $\begin{array}{c}58.7- \\
104.6^{\mathrm{B}}\end{array}$ & 0,001 & $80.8(80)$ \\
\hline PLT & $\mathrm{x} 10^{3} / \mathrm{mL}$ & $\begin{array}{c}429.4- \\
884.9\end{array}$ & $\begin{array}{c}414.3- \\
899.3\end{array}$ & $\begin{array}{c}312.9- \\
932.6\end{array}$ & $\begin{array}{c}403.5- \\
899.5\end{array}$ & $\begin{array}{c}439.1- \\
943.1\end{array}$ & $\begin{array}{c}327.1- \\
883.3\end{array}$ & 0.051 & $\begin{array}{l}656.3 \\
(660)\end{array}$ \\
\hline WBC & cell $/ \mathrm{mL}$ & $\begin{array}{c}7453- \\
21132^{\mathrm{B}}\end{array}$ & $\begin{array}{c}9627- \\
22928^{B}\end{array}$ & $\begin{array}{c}7464-^{-} \\
20612^{\mathrm{B}}\end{array}$ & $\begin{array}{c}9508- \\
18906^{\mathrm{B}}\end{array}$ & $\begin{array}{c}6041- \\
19375^{\mathrm{A}}\end{array}$ & $\begin{array}{l}8700 \\
-20025^{A}\end{array}$ & 0,001 & $\begin{array}{c}13283 \\
(13090)\end{array}$ \\
\hline Eos & $\%$ & $0-5.5^{\mathrm{A}}$ & $0-5.6^{\mathrm{A}}$ & $0-9.6^{\mathrm{A}}$ & $0-9.5^{\mathrm{A}}$ & $0-10.2^{\mathrm{B}}$ & $0-11.6^{\mathrm{A}}$ & 0,000 & $2.5(1)$ \\
\hline Lymph & $\%$ & $9.2-40^{\mathrm{A}}$ & $7.9-44.3^{\mathrm{A}}$ & $7.9-45.1^{\mathrm{A}}$ & $7.6-41.5^{\mathrm{A}}$ & $\begin{array}{c}15- \\
39.6^{\mathrm{B}}\end{array}$ & $\begin{array}{c}7.9- \\
42.7^{\mathrm{B}}\end{array}$ & 0,000 & $26.5(26)$ \\
\hline Mono & $\%$ & $0.7-9.8$ & $0-6$ & $0.8-11$ & $0.7-5.7$ & $0.6-11.2$ & $1-8$ & 0,900 & $2.6(2)$ \\
\hline Seg & $\%$ & $\begin{array}{l}51.6- \\
87.7^{\mathrm{B}}\end{array}$ & $\begin{array}{l}48.9- \\
92.3^{\mathrm{B}}\end{array}$ & $\begin{array}{l}47.2- \\
96.6^{\mathrm{B}}\end{array}$ & $45.8-91.6^{\mathrm{B}}$ & $\begin{array}{l}49.8- \\
85.3^{\mathrm{A}}\end{array}$ & $\begin{array}{l}50.3^{-} \\
89.2^{\mathrm{A}}\end{array}$ & 0,001 & $\begin{array}{c}68.3 \\
(69.4)\end{array}$ \\
\hline \multicolumn{10}{|c|}{ Pre-insemination $^{2}$} \\
\hline Hct & $\%$ & $25-39.9^{a}$ & $27.9-44^{b}$ & $30.3-40.9$ & $27-42$ & $\begin{array}{c}29.5- \\
39.9\end{array}$ & $\begin{array}{c}25.7- \\
43.6\end{array}$ & 0,04 & 35.9 (36) \\
\hline $\mathrm{Hb}$ & $\mathrm{g} / \mathrm{L}$ & $\begin{array}{l}69.6- \\
131.7^{\mathrm{a}}\end{array}$ & $\begin{array}{l}88.5- \\
136.6^{b}\end{array}$ & $\begin{array}{l}95.2- \\
135.1\end{array}$ & $\begin{array}{l}92.3- \\
132.6\end{array}$ & $\begin{array}{l}85.7- \\
138.8\end{array}$ & $\begin{array}{l}80.5- \\
104.2\end{array}$ & 0,001 & $\begin{array}{l}111.7 \\
(112)\end{array}$ \\
\hline $\mathrm{PP}$ & $g / L$ & $63.7-81^{\mathrm{A}}$ & $\begin{array}{l}62.3- \\
88.4^{\mathrm{A}}\end{array}$ & $\begin{array}{l}62.6- \\
86.7^{\mathrm{A}}\end{array}$ & $66-87.2^{\mathrm{A}}$ & $\begin{array}{l}68.7^{-} \\
90.7^{\mathrm{B}}\end{array}$ & $\begin{array}{l}66.4^{-} \\
97.1^{\mathrm{B}}\end{array}$ & 0,002 & $77.7(78)$ \\
\hline PLT & $\mathrm{x} 10^{3} / \mathrm{mL}$ & $\begin{array}{c}444- \\
736.1^{\mathrm{a}}\end{array}$ & $\begin{array}{c}477.1- \\
1076.3^{b}\end{array}$ & $\begin{array}{c}289.2- \\
917.2\end{array}$ & $\begin{array}{c}414.8- \\
828.6\end{array}$ & $\begin{array}{c}434.6- \\
834.6\end{array}$ & $\begin{array}{c}271.3- \\
947.5\end{array}$ & 0,03 & $\begin{array}{l}621.3 \\
(620)\end{array}$ \\
\hline WBC & cell $/ \mathrm{mL}$ & $\begin{array}{c}8008- \\
18902^{\mathrm{Ba}}\end{array}$ & $\begin{array}{c}10612- \\
20848^{\mathrm{Bb}}\end{array}$ & $\begin{array}{c}11065- \\
19647^{\mathrm{AB}}\end{array}$ & $\begin{array}{c}10356- \\
18337 \text { АВ }\end{array}$ & $\begin{array}{c}9906- \\
17760^{\mathrm{A}}\end{array}$ & $\begin{array}{c}7565- \\
23410^{\mathrm{A}}\end{array}$ & 0,02 & $\begin{array}{l}13990.2 \\
(13850)\end{array}$ \\
\hline Eos & $\%$ & $0-9$ & $0-9.8$ & $0-11.2$ & $0-11.4$ & $0.5-15$ & $0-11.1$ & 0,029 & $4.2(3.8)$ \\
\hline Lymph & $\%$ & $\begin{array}{c}20.1- \\
49.3\end{array}$ & $15.8-47.8$ & $15.8-47$ & $13.3-47.9$ & $\begin{array}{c}20.2- \\
46.3\end{array}$ & $9.7-42.4$ & 0,081 & $\begin{array}{c}31.8 \\
(32.2)\end{array}$ \\
\hline Mono & $\%$ & $0.7-9.8$ & $0.6-13.2$ & $1.4-7.6$ & $0.8-10.4$ & $1.9-7.9$ & $1-9.1$ & 0,052 & $3.6(3)$ \\
\hline Seg & $\%$ & $\begin{array}{l}42.8- \\
79.4\end{array}$ & $40.2-81.4$ & $43.5-76.2$ & $41.5-80.5$ & $\begin{array}{c}45.9- \\
68.1\end{array}$ & $48-88.9$ & 0,07 & $60.4(60)$ \\
\hline
\end{tabular}

: = hematocrit; $\mathrm{Hb}=$ hemoglobin; $\mathrm{PP}=$ plasma protein; $\mathrm{PLT}=$ platelets $\mathrm{WBC}=$ white blood cell count; Seg = segmented neutrophils.

Body condition; 1: thin; 2: optimal; and 3: fat, according to the Charalette scale ${ }^{12}$.

is for the main effect of parity and the main effect of BC within the same parity in data subjected to ANOVA and Tukey test or Kruskal-Wallis and par test, normality depending.

nges within a row with different superscripts indicate significant differences between parities $(P<.05)$.

res within a row with different superscripts indicate significant differences between BC in the same parity $(P<0.05)$.

เrity: first (parity 1), second (parity 2), third or more (parity 3)

5 days before insemination. 
Table 2: Hematological values of sows with different parities ${ }^{1}$ and body condition during pregnancy (T3, T4, T5).

\begin{tabular}{|c|c|c|c|c|c|c|c|c|c|}
\hline \multirow[b]{2}{*}{ Parameter } & \multirow[b]{2}{*}{ Unit } & \multicolumn{2}{|c|}{ Parity 1} & \multicolumn{2}{|c|}{ Parity 2} & \multicolumn{2}{|c|}{ Parity 3} & & \multirow{2}{*}{$\begin{array}{c}\text { Herd } \\
\text { average } \\
\text { (median) }\end{array}$} \\
\hline & & $\begin{array}{c}\text { BC } 1 \\
\mathrm{n}=24 \\
\end{array}$ & $\begin{array}{c}\text { BC } 2 \\
\mathrm{n}=32 \\
\end{array}$ & $\begin{array}{c}\text { BC } 1 \\
\mathrm{n}=28 \\
\end{array}$ & $\begin{array}{c}\text { BC } 2 \\
\mathrm{n}=38 \\
\end{array}$ & $\begin{array}{c}\text { BC } 1 \\
\mathrm{n}=55 \\
\end{array}$ & $\begin{array}{c}\text { BC } 2 \\
\mathrm{n}=130\end{array}$ & & \\
\hline \multicolumn{10}{|l|}{ Day 35} \\
\hline Hct & $\%$ & $30.9-45^{\mathrm{Ba}}$ & $\begin{array}{l}33.3^{-} \\
44.5^{\mathrm{Bb}}\end{array}$ & $\begin{array}{c}31- \\
48.3^{\mathrm{AB}}\end{array}$ & $\begin{array}{c}29.4- \\
43.7^{\mathrm{AB}}\end{array}$ & $\begin{array}{l}24.4^{-} \\
42.4^{\mathrm{A}}\end{array}$ & $\begin{array}{l}25.9- \\
47.6^{\mathrm{A}}\end{array}$ & 0,043 & $\begin{array}{l}37.9 \\
(38)\end{array}$ \\
\hline $\mathrm{Hb}$ & $\mathrm{g} / \mathrm{L}$ & $\begin{array}{c}83.8- \\
138.3^{\mathrm{ABa}}\end{array}$ & $\begin{array}{c}95.3- \\
150.5^{\mathrm{ABb}}\end{array}$ & $\begin{array}{c}97.3- \\
168.3^{\mathrm{B}}\end{array}$ & $\begin{array}{c}98.4- \\
141.9^{\mathrm{B}}\end{array}$ & $\begin{array}{c}78.6- \\
146.6^{\mathrm{A}}\end{array}$ & $\begin{array}{c}76.2- \\
149.7^{\mathrm{A}}\end{array}$ & 0,010 & $\begin{array}{l}118.7 \\
(119)\end{array}$ \\
\hline PP & $\mathrm{g} / \mathrm{L}$ & $66.3-95.9$ & $62.3-82.9$ & $59-93$ & $65.2-87.8$ & $67-118.6$ & $65.8-94$ & 0,423 & $\begin{array}{l}76.7 \\
(76)\end{array}$ \\
\hline PLT & $\mathrm{x} 10^{3} / \mathrm{mL}$ & $\begin{array}{c}186.4- \\
878.3\end{array}$ & $\begin{array}{c}181.6- \\
958.4\end{array}$ & $\begin{array}{c}129.3- \\
812.4\end{array}$ & $\begin{array}{c}223.4- \\
1027\end{array}$ & $\begin{array}{c}204.6- \\
859.5\end{array}$ & $\begin{array}{c}236.4- \\
857.3\end{array}$ & 0,081 & $\begin{array}{l}557.9 \\
(574)\end{array}$ \\
\hline WBC & cell $/ \mathrm{mL}$ & $\begin{array}{c}8079.4- \\
20893.9^{\mathrm{B}} \\
\end{array}$ & $\begin{array}{l}12257.3- \\
20077.5^{\mathrm{B}}\end{array}$ & $\begin{array}{c}9257.2- \\
21497.8^{\mathrm{B}} \\
\end{array}$ & $\begin{array}{r}9915.7- \\
19050.5^{\mathrm{B}} \\
\end{array}$ & $\begin{array}{r}8806.5- \\
17813.5^{\mathrm{A}} \\
\end{array}$ & $\begin{array}{r}9790- \\
31140^{\mathrm{A}} \\
\end{array}$ & 0,027 & $\begin{array}{l}14466.2 \\
(14400) \\
\end{array}$ \\
\hline \multicolumn{10}{|l|}{ Day 60} \\
\hline Hct & $\%$ & $\begin{array}{l}25.9- \\
44.1^{\mathrm{a}}\end{array}$ & $\begin{array}{l}30.3^{-} \\
44.9^{\mathrm{b}}\end{array}$ & $29.1-43.7$ & $29.5-43.9$ & $\begin{array}{c}23.5- \\
40.2\end{array}$ & $\begin{array}{c}28.9- \\
41.6\end{array}$ & 0,000 & $\begin{array}{l}36.1 \\
(36)\end{array}$ \\
\hline $\mathrm{Hb}$ & $\mathrm{g} / \mathrm{L}$ & $81-139.7$ & $\begin{array}{l}94.3- \\
145.4\end{array}$ & $\begin{array}{l}87.2- \\
134.6\end{array}$ & $\begin{array}{l}83.9- \\
139.8\end{array}$ & $\begin{array}{l}81.2- \\
151.3\end{array}$ & $\begin{array}{l}82.8- \\
145.1\end{array}$ & 0,01 & $\begin{array}{l}111.8 \\
(111)\end{array}$ \\
\hline PP & $\mathrm{g} / \mathrm{L}$ & $62-82.3^{A}$ & $\begin{array}{l}62.8^{-} \\
93.5^{\mathrm{A}}\end{array}$ & $\begin{array}{c}65.7- \\
133.8^{\mathrm{AB}}\end{array}$ & $\begin{array}{c}63.8^{-} \\
95.3^{\mathrm{AB}}\end{array}$ & $\begin{array}{c}64.5- \\
101.9^{\mathrm{B}}\end{array}$ & $\begin{array}{l}66.9- \\
110^{\mathrm{B}}\end{array}$ & 0,04 & $\begin{array}{l}79.4 \\
(78)\end{array}$ \\
\hline PLT & $\mathrm{x} 10^{3} / \mathrm{mL}$ & $\begin{array}{c}211.8- \\
890\end{array}$ & $\begin{array}{c}281.9- \\
965.1\end{array}$ & $\begin{array}{l}222- \\
851.9\end{array}$ & $\begin{array}{c}261.1- \\
762.8\end{array}$ & $\begin{array}{c}261.5- \\
819\end{array}$ & $\begin{array}{c}315.8- \\
944.7\end{array}$ & 0,080 & $\begin{array}{c}557.6 \\
(553.5)\end{array}$ \\
\hline WBC & cell $/ \mathrm{mL}$ & $\begin{array}{c}7830.5- \\
19605.3^{\mathrm{B}} \\
\end{array}$ & $\begin{array}{l}10213.4- \\
18627.6^{\mathrm{B}}\end{array}$ & $\begin{array}{c}9073.4- \\
18404.2^{\mathrm{A}} \\
\end{array}$ & $\begin{array}{c}6371.5- \\
18051.4^{\mathrm{A}} \\
\end{array}$ & $\begin{array}{c}10526- \\
20511.6^{\mathrm{A}} \\
\end{array}$ & $\begin{array}{l}9125.1- \\
21340^{\mathrm{A}} \\
\end{array}$ & 0,000 & $\begin{array}{r}13698.2 \\
(13700) \\
\end{array}$ \\
\hline \multicolumn{10}{|l|}{ Day 90} \\
\hline Hct & $\%$ & $\begin{array}{l}29.9- \\
45.4^{\mathrm{B}}\end{array}$ & $\begin{array}{l}30.1- \\
42.9^{\mathrm{B}}\end{array}$ & $\begin{array}{c}29.7- \\
41.9^{\mathrm{AB}}\end{array}$ & $\begin{array}{c}26.7- \\
44.4^{\mathrm{AB}}\end{array}$ & $\begin{array}{l}26.7^{-} \\
39.8^{\mathrm{A}}\end{array}$ & $\begin{array}{c}25- \\
44.2^{\mathrm{A}}\end{array}$ & 0,000 & $\begin{array}{l}35.1 \\
(35)\end{array}$ \\
\hline $\mathrm{Hb}$ & $\mathrm{g} / \mathrm{L}$ & $81-129^{B}$ & $87.2-145^{B}$ & $\begin{array}{c}89.6- \\
132.8^{\mathrm{A}}\end{array}$ & $\begin{array}{c}82.3 \\
-135.1^{\mathrm{A}}\end{array}$ & $\begin{array}{l}75.8- \\
139^{\mathrm{A}}\end{array}$ & $\begin{array}{c}88.5- \\
149.4^{\mathrm{A}}\end{array}$ & 0,000 & $\begin{array}{l}108.6 \\
(108)\end{array}$ \\
\hline PP & $\mathrm{g} / \mathrm{L}$ & $\begin{array}{l}63.2- \\
86.4^{\mathrm{A}}\end{array}$ & $\begin{array}{l}59.6- \\
72.4^{\mathrm{A}}\end{array}$ & $\begin{array}{c}69.4- \\
94.6^{\mathrm{AB}}\end{array}$ & $\begin{array}{c}69.1- \\
97.4^{\mathrm{AB}}\end{array}$ & $\begin{array}{c}70.3- \\
118.2^{\mathrm{B}}\end{array}$ & $\begin{array}{c}72- \\
110.1^{\mathrm{B}}\end{array}$ & 0,001 & $\begin{array}{l}79.8 \\
(80)\end{array}$ \\
\hline PLT & $\mathrm{x} 10^{3} / \mathrm{mL}$ & $\begin{array}{c}210.8- \\
863.1\end{array}$ & $\begin{array}{l}77.2- \\
826.6\end{array}$ & $\begin{array}{c}131.2- \\
848.7\end{array}$ & $\begin{array}{c}169.2- \\
681.7\end{array}$ & $\begin{array}{c}123.1- \\
784.7\end{array}$ & $\begin{array}{c}141.9- \\
769.6\end{array}$ & 0,08 & $\begin{array}{c}405 \\
(378.5)\end{array}$ \\
\hline WBC & cell $/ \mathrm{mL}$ & $\begin{array}{c}9412.4- \\
17240^{\mathrm{B}}\end{array}$ & $\begin{array}{c}4466.9- \\
19640.9^{\mathrm{B}}\end{array}$ & $\begin{array}{c}6394- \\
17021.2^{\mathrm{B}}\end{array}$ & $\begin{array}{c}7673.2- \\
17325.7^{\mathrm{B}}\end{array}$ & $\begin{array}{c}6455.6- \\
16504.1^{\mathrm{A}}\end{array}$ & $\begin{array}{l}5780- \\
6510^{\mathrm{A}}\end{array}$ & 0,000 & $\begin{array}{l}12062.5 \\
(12225)\end{array}$ \\
\hline
\end{tabular}

; = hematocrit; $\mathrm{Hb}=$ hemoglobin; $\mathrm{PP}=$ plasma protein; $\mathrm{PLT}=$ platelets; $\mathrm{WBC}=$ white blood cell count; Seg $=$ segmented neutrophils.

Body condition; 1: thin; 2: optimal; and 3: fat, according to the Charalette scale ${ }^{12}$.

is for the main effect of parity and the main effect of BC within the same parity in data subjected to ANOVA and Tukey test or Kruskal-Wallis and par test, normality depending.

Zanges within a row with different superscripts indicate significant differences between parities $(P<0.05)$.

es within a row with different superscripts indicate significant differences between BC in the same parity $(P<0.05)$.

เrity: first (parity 1), second (parity 2), third or more (parity 3) 
Table 3: Hematological values of sows with different parities ${ }^{1}$ and body condition after pregnancy (subsequent weaning).

\begin{tabular}{|c|c|c|c|c|c|c|c|c|c|}
\hline \multirow[b]{2}{*}{ Parameter } & \multirow[b]{2}{*}{ Unit } & \multicolumn{2}{|c|}{ Parity 1} & \multicolumn{2}{|c|}{ Parity 2} & \multicolumn{2}{|c|}{ Parity 3} & & \multirow{2}{*}{$\begin{array}{c}\text { Herd } \\
\text { average } \\
\text { (median) }\end{array}$} \\
\hline & & $\begin{array}{c}\text { BC 1 } \\
\mathrm{n}=24 \\
\end{array}$ & $\begin{array}{c}\text { BC } 2 \\
\mathrm{n}=32\end{array}$ & $\begin{array}{c}\text { BC } 1 \\
\mathrm{n}=28\end{array}$ & $\begin{array}{c}\text { BC } 2 \\
\mathrm{n}=38\end{array}$ & $\begin{array}{c}\text { BC } 1 \\
\mathrm{n}=55\end{array}$ & $\begin{array}{c}\text { BC } 2 \\
\mathrm{n}=130\end{array}$ & & \\
\hline Hct & $\%$ & $\begin{array}{c}28.3- \\
40.1\end{array}$ & $27.5-42.2$ & $\begin{array}{c}24.9- \\
43.2\end{array}$ & $\begin{array}{c}26.9- \\
42.5\end{array}$ & $\begin{array}{c}26.6- \\
37.7\end{array}$ & $\begin{array}{c}27.5- \\
40.6\end{array}$ & 0.063 & $33.8(34)$ \\
\hline $\mathrm{Hb}$ & $\mathrm{g} / \mathrm{L}$ & $\begin{array}{l}66.5 \\
-119\end{array}$ & $78.9-130.9$ & $\begin{array}{l}87.9- \\
141.6\end{array}$ & $\begin{array}{l}76.1- \\
140.3\end{array}$ & $\begin{array}{l}75.6- \\
124.2\end{array}$ & $\begin{array}{c}83- \\
135.9\end{array}$ & 0.051 & $102.1(102)$ \\
\hline $\mathrm{PP}$ & $\mathrm{g} / \mathrm{L}$ & $\begin{array}{l}69.1^{-} \\
87.1^{\mathrm{A}}\end{array}$ & $\begin{array}{l}69.3- \\
91.1^{\mathrm{A}}\end{array}$ & $\begin{array}{l}71.4- \\
89.8^{\mathrm{B}}\end{array}$ & $\begin{array}{c}71.8^{-} \\
100.7^{\mathrm{B}}\end{array}$ & $\begin{array}{l}72.5 \text { - } \\
94.6^{\mathrm{B}}\end{array}$ & $\begin{array}{l}74.8- \\
100^{\mathrm{B}}\end{array}$ & 0.020 & $82.1(82)$ \\
\hline PLT & $\mathrm{x} 10^{3} / \mathrm{mL}$ & $\begin{array}{c}133.2- \\
801.6\end{array}$ & $\begin{array}{l}220.1- \\
1018.8\end{array}$ & $\begin{array}{c}239.2- \\
857\end{array}$ & $\begin{array}{c}221.8- \\
834.9\end{array}$ & $\begin{array}{c}124.6- \\
775.9\end{array}$ & $\begin{array}{c}171.5- \\
930.1\end{array}$ & 0.068 & $\begin{array}{c}479.5 \\
(458.5)\end{array}$ \\
\hline WBC & cell/mL & $\begin{array}{c}6376- \\
16141^{\mathrm{a}}\end{array}$ & $\begin{array}{l}10796.6- \\
17360.1^{b}\end{array}$ & $\begin{array}{l}8009.5- \\
17415.9\end{array}$ & $\begin{array}{l}9606.7- \\
17840.1\end{array}$ & $\begin{array}{l}7454.8- \\
15680.4\end{array}$ & $\begin{array}{l}6790- \\
19685\end{array}$ & 0,027 & $\begin{array}{l}12958.7 \\
(12965)\end{array}$ \\
\hline Eos & $\%$ & $0-10.5$ & $0-11$ & $0-8.2$ & $0-9.9$ & $0-11.1$ & $0-12.6$ & 0.057 & $3.6(2)$ \\
\hline Lymph & $\%$ & $\begin{array}{c}9.8- \\
55.6^{\mathrm{B}}\end{array}$ & $7.8-44.4^{\mathrm{B}}$ & $4.1-42.5^{\mathrm{A}}$ & $7.7-40^{\mathrm{A}}$ & $\begin{array}{c}5.2- \\
40.1^{\mathrm{AB}}\end{array}$ & $\begin{array}{c}9- \\
43.1^{\mathrm{AB}}\end{array}$ & 0,01 & $25.7(25)$ \\
\hline Mono & $\%$ & $0-6.4$ & $0.6-8$ & $0.2-7.4$ & $0.9-8.7$ & $0.9-6$ & $1-5.6$ & 0.052 & $2.8(2)$ \\
\hline Seg & $\%$ & $\begin{array}{l}38.4- \\
89.3^{\mathrm{a}}\end{array}$ & $41-88.7^{b}$ & $\begin{array}{c}47.3- \\
95.1\end{array}$ & $\begin{array}{c}45.4- \\
90.1\end{array}$ & $\begin{array}{c}47.6- \\
87.2\end{array}$ & $\begin{array}{c}50.7- \\
89.1\end{array}$ & 0,00 & $67.9(68)$ \\
\hline
\end{tabular}

; = hematocrit $\mathrm{Hb}=$ hemoglobin; $\mathrm{PP}=$ plasma protein; $\mathrm{PLT}=$ platelets; $\mathrm{WBC}=$ white blood cell count; Eos = eosinophils; Lymph = lymphocytes; Mono = monocytes; Seg = segmented neutrophils.

Body condition; 1: thin; 2: optimal; and 3: fat, according to the Charalette scale ${ }^{12}$.

s for the main effect of parity and the main effect of BC within the same parity in data subjected to ANOVA and Tukey test or Kruskal-Wallis and par test, normality depending.

langes within a row with different superscripts indicate significant differences between parities $(P<0.05)$.

es within a row with different superscripts indicate significant differences between $\mathrm{BC}$ in the same parity $(P<0.05)$.

urity: first (parity 1 ), second (parity 2 ), third or more (parity 3 )

\section{Figures}



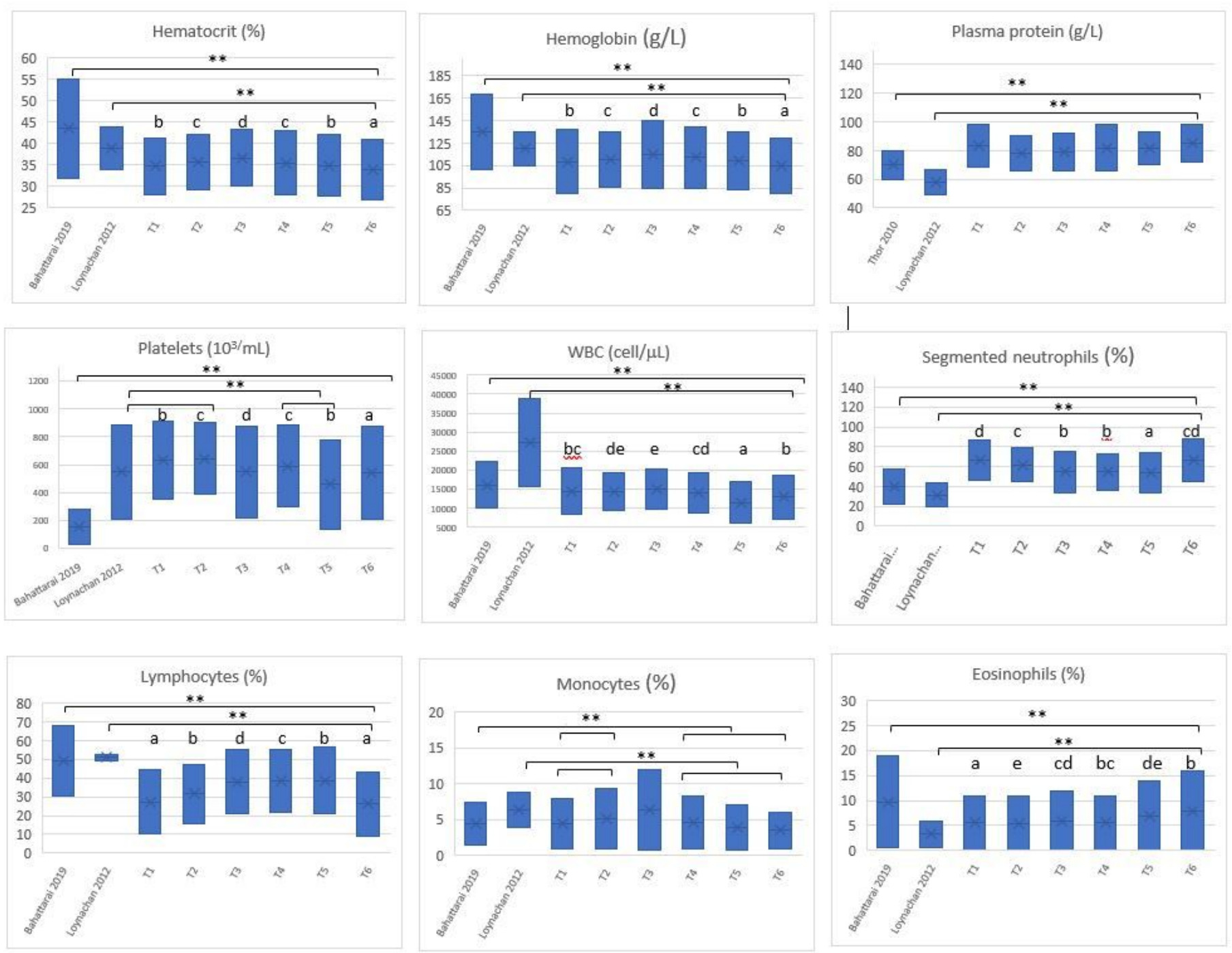

\section{Figure 1}

Hematological values ranges for sows at different stages of the reproductive cycle $(n=307)$ in relation to reference intervals from literature. 